\title{
Liquid Crystalline Order from Ortho-Phenylene Ethynylene Macrocycles
}

\author{
Sang Hyuk Seo, ${ }^{\dagger}$ Ticora V. Jones,${ }^{\perp}$ Helga Seyler, ${ }^{\ddagger}$ Jack O. Peters, ${ }^{\S}$ \\ Tae Hyung Kim, ${ }^{\perp}$ Ji Young Chang, ${ }^{\dagger}$ and Gregory N. Tew ${ }^{*, \perp}$ \\ School of Materials Science and Engineering, and Hyperstructured Organic \\ Materials Research center, College of Engineering, Seoul National \\ University, Seoul 151-742 Korea, Department of Chemistry, University of \\ Mainz, Germany, GE Water \& Process Technologies Research \& \\ Development 65 Grove St. Watertown, MA 02472, and Polymer Science and \\ Engineering, University of Massachusetts, Amherst, Massachusetts 01003 \\ tew@mail.pse.umass.edu
}

\section{Supporting Information}

Materials. Reagent grade tetrahydrofuran (THF) was distilled under nitrogen from sodium benzophenone. All other solvents were used as received. 3-Nitro-4-iodophenol and triethyleneglycol mono methyl ether were purchased from Aldrich and used without further purification. Trans dichlorobis (triphenylphosphine) palladium $\left(\mathrm{Pd}\left(\mathrm{PPh}_{3}\right)_{2} \mathrm{Cl}_{2}\right)$ was purchased from Strem Chemical. S(-)-2-methyl-1-butanol was purchased from Fluka Chemika. Trimethylsilyl acetylene was purchased from GFS chemicals. Methyl iodide was purchased from Alfa Aesar and distilled into an air-free flask for subsequent use. All other reagents were purchased from Alfa Aesar or Aldrich Chemical Co. and all were used as received. All column chromatography was performed with 80-230 mesh silica from VWR. Instrumentations. ${ }^{1} \mathrm{H}$ and ${ }^{13} \mathrm{C}$ NMR spectra were obtained a Bruker DPX $300\left({ }^{1} \mathrm{H}: 300\right.$ MHz and ${ }^{13} \mathrm{C}$ NMR: $125 \mathrm{MHz}$ ) spectrometer. ${ }^{13} \mathrm{C}$ NMR spectra were obtained at $100 \mathrm{MHz}$ on a JEOL Eclipse spectrometer. X-ray diffraction (XRD) patterns were recorded by Rigaku RU-H3R rotating anode X-ray diffractometer $(\mathrm{Cu} \mathrm{K \alpha}$ radiation, $\lambda=1.54 \AA$ ). Samples for XRD were sandwiched between two Mylar films or Imide films. SAXD data were collected using a point-collimated incident beam under vacuum to reduce air scatter on an image plate and scanned for analysis. Thermal analyses were performed by a TA modulated DSC 2910. An optical microscopy study was performed on an OLYMPUS BX60 equipped with a Mettler Toledo FP 82 HT heating stage and a Mettler Toledo FP 80 central process controller. UV-vis spectra were recorded on a Hewlett-Packard 8453. Emission and excitation spectra were taken on a Perkin-Elmer LS 50B spectrometer with a xenon lamp light source and $1 \mathrm{~cm}$ quartz cell. The maximum absorbtivities of the solutions were 0.1 or less. HPLC data were obtained on a Waters Alliance 2695 HPLC using a Waters 2996 Photodiode Array detector monitoring at $290 \mathrm{~nm}$ using solutions of $1 \mathrm{mg} / \mathrm{ml}$ or less. 
Traces were analyzed using Empower software. Mass spectral data were obtained at the University of Massachusetts Amherst mass spec facility, which is supported in part by the National Science Foundation.

Abbreviation used: DCM (dichloromethane), TEA (triethylamine), TMS (trimethylsilyl), TEG (triethyleneglycol), $\mathrm{C}_{5} *$ ((s)-2-methyl-butane).

TMS-Monomer-Triazene (1a-1b), TMS-Dimer-Triazene (2a-2b), and TMS-TrimerTriazene (3a-3b) were synthesized according to the literature. ${ }^{4 a, 4 c}$

TMS-3C 5 *-Trimer-I (4a) A schlenk flask with stir bar was flame dried under vacuum and backfilled with nitrogen three times. The triazene compound 3a $(30.00 \mathrm{mg})$ was dissolved in enough distilled methyl iodide to make a $0.1 \mathrm{M}$ solution and transferred to the schlenk flask. The schlenk flask was then gently degassed for 30 seconds and backfilled with nitrogen before sealing. The reaction vessel was placed in a $110{ }^{\circ} \mathrm{C}$ oil bath for $6-20 \mathrm{~h}$ and monitored by TLC. A precipitate should form. Upon completion the reaction mixture was diluted with hexanes, filtered over Celite, concentrated, and purified by flash column chromatography (10\% DCM : hexanes) to afford $27.50 \mathrm{mg}(88 \%)$ of $4 \mathbf{a}$ as a beige oil/solid.

${ }^{1} \mathrm{H}$ NMR $\left(\mathrm{CDCl}_{3}\right): \delta 7.48(\mathrm{~d}, 2 \mathrm{H}$, phenyl $\mathrm{H}, \mathrm{J}=8.62 \mathrm{~Hz}), 7.38(\mathrm{~d}, 1 \mathrm{H}$, phenyl $\mathrm{H}, \mathrm{J}=8.60$ $\mathrm{Hz}), 7.37$ (d, 1H, phenyl H, J = 2.47 Hz), $7.10(\mathrm{~d}, 1 \mathrm{H}$, phenyl H, J = 2.46 Hz), 7.03 (d, 1H, phenyl H, J = 2.51 Hz), 6.76-6.88 (m, 3H, phenyl ), 3.59-3.90 (m, 6H, $\left.\mathrm{CH}_{2}\right), 1.72-1.95(\mathrm{~m}$, $3 \mathrm{H}, \mathrm{CH}), 1.42-1.66\left(\mathrm{~m}, 3 \mathrm{H}, \mathrm{CH}_{2}\right), 1.18-1.36\left(\mathrm{~m}, 3 \mathrm{H}, \mathrm{CH}_{2}\right), 0.84-1.07\left(\mathrm{~m}, 18 \mathrm{H}, \mathrm{CH}_{3}\right), 0.21$ $\left(\mathrm{s}, 9 \mathrm{H}, \mathrm{CH}_{3}\right) \mathrm{ppm}$.

H-3C ${ }_{5}$-Trimer-I (5a) One equivalent of the compound 4a (110.00 mg) and 3 molar equivalents of $\mathrm{K}_{2} \mathrm{CO}_{3}$ with methanol $(11 \mathrm{~mL})$ and $\mathrm{THF}(0.55 \mathrm{~mL})$ were stirred in a nitrogen-flushed flask for 0.5 to $4 \mathrm{~h}$. Reaction was monitored by TLC. Upon completion, the solution was diluted with ethyl acetate and water and washed twice with water. After drying the ethyl acetate layer over $\mathrm{MgSO}_{4}$ and evaporation of solvent, the residue was purified by flash column chromatography (40\% DCM : hexanes) to afford $87.00 \mathrm{mg}$ $(85 \%)$ of $\mathbf{5 a}$.

${ }^{1} \mathrm{H} \mathrm{NMR}\left(\mathrm{CDCl}_{3}\right): \delta 7.51(\mathrm{~d}, 2 \mathrm{H}$, phenyl H, J = 8.62 Hz), $7.42(\mathrm{~d}, 1 \mathrm{H}$, phenyl $\mathrm{H}, \mathrm{J}=8.60$ $\mathrm{Hz}), 7.39$ (d, 1H, phenyl H, J = 2.47 Hz), 7.11 (d, 1H, phenyl H, J = 2.46 Hz), 7.07 (d, 1H, phenyl $\mathrm{H}, \mathrm{J}=2.51 \mathrm{~Hz}), 6.78-6.90\left(\mathrm{~m}, 3 \mathrm{H}\right.$, phenyl ), 3.69-3.88 (m, 6H, $\left.\mathrm{CH}_{2}\right), 3.14(\mathrm{~s}, 1 \mathrm{H}$, 
$\mathrm{CH}), 1.79-1.95(\mathrm{~m}, 3 \mathrm{H}, \mathrm{CH}), 1.46-1.62\left(\mathrm{~m}, 3 \mathrm{H}, \mathrm{CH}_{2}\right), 1.18-1.36\left(\mathrm{~m}, 3 \mathrm{H}, \mathrm{CH}_{2}\right), 0.84-1.05$ $\left(\mathrm{m}, 18 \mathrm{H}, \mathrm{CH}_{3}\right) \mathrm{ppm}$.

3C $_{5}$ *-Macrocycle (M1) The general procedure for intramolecular Sonogashira crosscoupling was performed. $3.14 \mathrm{mg} \mathrm{Pd}\left(\mathrm{PPh}_{3}\right)_{2} \mathrm{Cl}_{2}(4.47 \mu \mathrm{mol}, 0.05 \mathrm{~mol}$ eq. $), 1.70 \mathrm{mg} \mathrm{CuI}$ ( $8.93 \mu \mathrm{mol}, 0.1 \mathrm{~mol}$ eq.) and TEA were added to the air free flask under nitrogen, and then the solution was gently degassed for 30 minutes. $60.00 \mathrm{mg}$ of $\mathbf{5 a}(89.30 \mu \mathrm{mol})$ was dissolved in TEA $(0.05 \mathrm{M})$ and added to the solution with a syringe pump $(1.80 \mathrm{ml}$ solution, flow rate: $0.08 \mathrm{~mL} / \mathrm{h}, 5 \mathrm{~mL}$ syringe). The reaction solution was heated at $65{ }^{\circ} \mathrm{C}$ during the $24 \mathrm{~h}$. Once done, the reaction solution was diluted with ether, filtered through a pad of Celite and concentrated. The oil was then purified using column chromatography in $25 \%$ DCM : hexanes to afford the product (12.00 mg. $25 \%)$ as a sticky compound M1.

${ }^{1} \mathrm{H}$ NMR $\left(\mathrm{CDCl}_{3}\right): \delta 7.24(\mathrm{~d}, 3 \mathrm{H}$, phenyl $\mathrm{H}, \mathrm{J}=8.70 \mathrm{~Hz}), 6.85(\mathrm{~d}, 3 \mathrm{H}$, phenyl $\mathrm{H}, \mathrm{J}=2.70$ $\mathrm{Hz}), 6.72,6.69\left(\mathrm{dd}, 3 \mathrm{H}\right.$, phenyl $\left.\mathrm{H}, \mathrm{J}_{1}=8.55 \mathrm{~Hz}, \mathrm{~J}_{2}=2.50 \mathrm{~Hz}\right), 3.80-3.73\left(\mathrm{~m}, 6 \mathrm{H}, \mathrm{OCH}_{2}\right)$, 1.82-1.92 (m, $3 \mathrm{H}, \mathrm{CH}_{2}$ ), 1.46-1.64 (m, 3H, $\mathrm{CH}_{2}$ ), 1.23-1.38 (m, 3H, $\left.\mathrm{CH}_{2}, \mathrm{CH}_{3}\right), 0.88-1.03$ (m, 18H, $\left.\mathrm{CH}_{3}\right)$ ppm. ${ }^{13} \mathrm{C} \mathrm{NMR}\left(\mathrm{CDCl}_{3}\right): \delta 152.25,134.03,128.59,127.05,121.42,113.79$, 91.19, 76.80, 38.96, 29.72, 16.51, 11.32. ppm. MS: $m / z 558.4\left(\mathrm{~m}+\mathrm{H}^{+}\right)$. HPLC $\left(\mathrm{CH}_{3} \mathrm{CN}\right)$ $3.75 \min (100 \%)$.

TMS-3TEG-Trimer-I (4b) A schlenk flask with stir bar was flame dried under vacuum and backfilled with nitrogen three times. The triazene compound $\mathbf{3 b}(0.26 \mathrm{~g})$ was dissolved in enough distilled methyl iodide to make a $0.1 \mathrm{M}$ solution and transferred to the schlenk flask. The schlenk flask was then gently degassed for 30 seconds and backfilled with nitrogen before sealing. The reaction vessel was placed in a $110{ }^{\circ} \mathrm{C}$ oil bath for $20 \mathrm{~h}$ and monitored by TLC. A precipitate should form. Upon completion the reaction mixture was diluted with hexanes, filtered over Celite, concentrated, and purified by flash column chromatography (20\% Acetone : DCM) to afford $0.24 \mathrm{~g}(90 \%)$ of $\mathbf{3}$ as a brown oil.

${ }^{1} \mathrm{H}$ NMR $\left(\mathrm{CDCl}_{3}\right): \delta 7.51,7.49\left(\mathrm{dd}, 2 \mathrm{H}\right.$, phenyl H, $\left.\mathrm{J}_{1}=5.1, \mathrm{~J}_{2}=8.7 \mathrm{~Hz}\right), 7.43(\mathrm{~d}, 1 \mathrm{H}$, phenyl $\mathrm{H}, \mathrm{J}=2.7$ ), 7.41 (d, $1 \mathrm{H}$ phenyl $\mathrm{H}, \mathrm{J}=9.0), 7.16(\mathrm{~d}, 1 \mathrm{H}$, phenyl $\mathrm{H}, \mathrm{J}=2.7 \mathrm{~Hz}$ ), 7.05 (d, 1H, phenyl $\mathrm{H}, \mathrm{J}=2.4 \mathrm{~Hz}$ ), $6.91(\mathrm{~d}, 1 \mathrm{H}$, phenyl $\mathrm{H}, \mathrm{J}=2.7), 6.89,6.82(\mathrm{dd}, 1 \mathrm{H}$, phenyl $\mathrm{H}$, $\left.\mathrm{J}_{1}=2.4 . \mathrm{J}_{2}=8.7 \mathrm{~Hz}\right), 6.88(\mathrm{~d}, 1 \mathrm{H}$, phenyl $\mathrm{H}, \mathrm{J}=2.1 \mathrm{~Hz}), 4.21-4.05\left(\mathrm{t}, 6 \mathrm{H}, \mathrm{CH}_{2}\right), 3.91-3.54$ (m, 30H), 3.39 (s. 9H, $\mathrm{CH}_{3}$ ), 0.20 (s, 9H, $\mathrm{Si}_{-} \mathrm{CH}_{3}$ ) ppm.

H-3TEG-Trimer-I (5b) One equivalent of the compound $4 \mathbf{b}(0.23 \mathrm{~g})$ and 3 molar equivalents of $\mathrm{K}_{2} \mathrm{CO}_{3}$ with methanol $(11 \mathrm{~mL})$ and THF $(0.55 \mathrm{~mL})$ were stirred in a 
nitrogen-flushed flask for 0.5 to $4 \mathrm{~h}$. Reaction was monitored by TLC. Upon completion, the solution was diluted with ethyl acetate and water and washed twice with water. After drying the ethyl acetate layer over $\mathrm{MgSO}_{4}$ and evaporation of solvent, the residue was purified by flash column chromatography (20\% Acetone : DCM) to afford $0.21 \mathrm{~g}(99 \%)$ of 5b.

${ }^{1} \mathrm{H}$ NMR $\left(\mathrm{CDCl}_{3}\right): \delta 7.51,7.49\left(\mathrm{dd}, 2 \mathrm{H}\right.$, phenyl $\left.\mathrm{H}, \mathrm{J}_{1}=7.2, \mathrm{~J}_{2}=8.7 \mathrm{~Hz}\right), 7.43(\mathrm{~d}, 1 \mathrm{H}$, phenyl $\mathrm{H}, \mathrm{J}=2.7), 7.41(\mathrm{~d}, 1 \mathrm{H}$ phenyl $\mathrm{H}, \mathrm{J}=4.8), 7.15(\mathrm{~d}, 1 \mathrm{H}$, phenyl $\mathrm{H}, \mathrm{J}=2.7 \mathrm{~Hz}), 7.08$ (d, 1H, phenyl H, J = 2.4 Hz), 6.93-6.84 (m, 3H, phenyl H, J = 2.4), 4.20-4.07 (t, 6H, $\mathrm{CH}_{2}$ ), 3.90-3.53 (m, 30H), 3.48 (s. 9H, $\left.\mathrm{CH}_{3}\right), 3.14$ (s, $\left.1 \mathrm{H}, \mathrm{CH}\right) \mathrm{ppm}$.

3TEG-Macrocycle (M2) The general procedure for intramolecular Sonogashira crosscoupling was performed. $8.13 \mathrm{mg} \mathrm{Pd}\left(\mathrm{PPh}_{3}\right)_{2} \mathrm{Cl}_{2}(11.60 \mu \mathrm{mol}, 0.05 \mathrm{~mol}$ eq.), $4.41 \mathrm{mg} \mathrm{CuI}$ ( $23.20 \mu \mathrm{mol}, 0.1 \mathrm{~mol}$ eq.) and TEA were added to the air free flask under nitrogen, and then the solution was gently degassed for 30 minutes. $0.21 \mathrm{~g}$ of $\mathbf{5 b}(0.23 \mathrm{mmol})$ was dissolved in TEA $(0.05 \mathrm{M})$ and added to the solution with a syringe pump $(4.60 \mathrm{ml}$ solution, flow rate: $0.08 \mathrm{~mL} / \mathrm{h}, 5 \mathrm{~mL}$ syringe). The reaction solution was heated at $65{ }^{\circ} \mathrm{C}$ during the $24 \mathrm{~h}$. Once done, the reaction solution was diluted with ether, filtered through a pad of Celite and concentrated. The oil was then purified using column chromatography (30\% Acetone : DCM) to afford the product (70.00 $\mathrm{mg} .38 \%$ ) as a oily compound $\mathbf{M 2}$.

${ }^{1} \mathrm{H}$ NMR $\left(\mathrm{CDCl}_{3}\right): \delta 7.24(\mathrm{~d}, 3 \mathrm{H}$, phenyl H, J = $8.40 \mathrm{~Hz}), 6.86(\mathrm{~d}, 3 \mathrm{H}$, phenyl $\mathrm{H}, \mathrm{J}=2.70$ $\mathrm{Hz}), 6.72,6.69\left(\mathrm{dd}, 3 \mathrm{H}\right.$, phenyl H, J $\left.\mathrm{J}_{1}=8.70 \mathrm{~Hz}, \mathrm{~J}_{2}=2.70 \mathrm{~Hz}\right), 4.14\left(\mathrm{t}, 6 \mathrm{H}, \mathrm{OCH}_{2}\right), 3.87(\mathrm{t}$, $\left.6 \mathrm{H}, \mathrm{CH}_{2}\right), 3.76-3.56\left(\mathrm{~m}, 24 \mathrm{H}, \mathrm{CH}_{2}\right), 3.40\left(\mathrm{~s}, 9 \mathrm{H}, \mathrm{OCH}_{3}\right) \mathrm{ppm} .{ }^{13} \mathrm{C} \mathrm{NMR}\left(\mathrm{CDCl}_{3}\right): \delta 159.09$, 133.53, 128.72, 118.73, 117.05, 115.71, 93.30, 91.43, 72.14, 71.10, 70.89, 70.82, 69.77, 67.76, 59.30. ppm. MS: $\mathrm{m} / \mathrm{z} 787.5\left(\mathrm{M}+\mathrm{H}^{+}\right)$. HPLC $\left(\mathrm{CH}_{3} \mathrm{CN}\right) 2.06 \mathrm{~min}(99 \%)$.

TMS-2TEG-1C ${ }_{5}{ }^{*}$-Trimer-Triazene (6) The general procedure for intramolecular Sonogashira cross-coupling was performed. $25.23 \mathrm{mg} \mathrm{Pd}\left(\mathrm{PPh}_{3}\right)_{2} \mathrm{Cl}_{2}(35.95 \mu \mathrm{mol}, 0.05 \mathrm{~mol}$

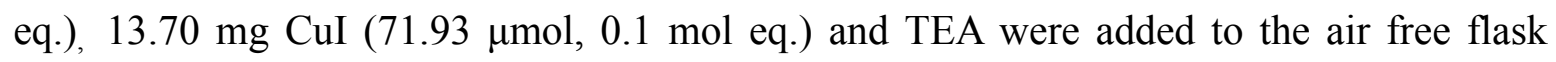
under nitrogen, and then the solution was gently degassed for 30 minutes. $0.45 \mathrm{~g}$ of deprotected dimer $\mathbf{2} \mathbf{b}^{\prime}(0.72 \mathrm{mmol})$ and $0.23 \mathrm{~g}$ of activated monomer 1a' $(0.60 \mathrm{mmol})$ was dissolved in TEA $(0.05 \mathrm{M})$ and added to the solution. The reaction solution was heated at $65{ }^{\circ} \mathrm{C}$ during the $24 \mathrm{~h}$. Once done, the reaction solution was diluted with ether, filtered through a pad of Celite and concentrated. The oil was then purified using column chromatography (30\% Acetone : DCM) to afford the product (0.32 g. $60 \%)$ as a sticky compound 6 . 
${ }^{1} \mathrm{H}$ NMR $\left(\mathrm{CDCl}_{3}\right): \delta 7.52(\mathrm{~d}, 1 \mathrm{H}$, phenyl $\mathrm{H}, \mathrm{J}=8.40 \mathrm{~Hz}), 7.48(\mathrm{~d}, 1 \mathrm{H}$, phenyl $\mathrm{H}, \mathrm{J}=8.40$ Hz), 7.39 (d, 1H, phenyl H, J = 8.70 Hz), $7.04(\mathrm{~d}, 1 \mathrm{H}$, phenyl H, J = 2.70 Hz) 6.99 (d, 1H, phenyl $\mathrm{H}, \mathrm{J}=2.70 \mathrm{~Hz}), 6.97(\mathrm{~d}, 1 \mathrm{H}$, phenyl $\mathrm{H}, \mathrm{J}=2.70 \mathrm{~Hz}), 6.87,6.84(\mathrm{dd}, 1 \mathrm{H}$, phenyl $\mathrm{H}$, $\left.\mathrm{J}_{1}=8.70 \mathrm{~Hz}, \mathrm{~J}_{2}=2.70 \mathrm{~Hz}\right), 6.78,6.75\left(\mathrm{dd}, 1 \mathrm{H}\right.$, phenyl H, $\left.\mathrm{J}_{1}=8.70 \mathrm{~Hz}, \mathrm{~J}_{2}=2.70 \mathrm{~Hz}\right), 6.66$, $6.64\left(\mathrm{dd}, 1 \mathrm{H}\right.$, phenyl H, $\left.\mathrm{J}_{1}=8.70 \mathrm{~Hz}, \mathrm{~J}_{2}=2.70 \mathrm{~Hz}\right), 4.15\left(\mathrm{t}, 4 \mathrm{H}, \mathrm{PhOCH}_{2}\right), 3.89-3.53(\mathrm{~m}$, $26 \mathrm{H}, \mathrm{OCH}_{2}$ ), 3.39 (s. $\left.6 \mathrm{H}, \mathrm{OCH}_{3}\right), 1.80-0.87$ (m, $\left.15 \mathrm{H}, \mathrm{CH}_{2}, \mathrm{CH}_{3}\right), 0.25$ (s, 9H, $\left.\mathrm{Si}_{-} \mathrm{CH}_{3}\right)$ ppm.

TMS-2TEG-1C $5_{5}$-Trimer-I (7) A schlenk flask with stir bar was flame dried under vacuum and backfilled with nitrogen three times. The triazene compound $6(0.07 \mathrm{~g})$ was dissolved in enough distilled methyl iodide to make a $0.1 \mathrm{M}$ solution and transferred to the schlenk flask. The schlenk flask was then gently degassed for 30 seconds and backfilled with nitrogen before sealing. The reaction vessel was placed in a $110{ }^{\circ} \mathrm{C}$ oil bath for $20 \mathrm{~h}$ and monitored by TLC. A precipitate should form. Upon completion the reaction mixture was diluted with hexanes, filtered over Celite, concentrated, and purified by flash column chromatography (100\% Ethyl acetate) to afford $69.00 \mathrm{mg}(95 \%)$ of 7 as a brown oil.

${ }^{1} \mathrm{H}$ NMR $\left(\mathrm{CDCl}_{3}\right): \delta 7.52(\mathrm{~d}, 1 \mathrm{H}$, phenyl H, $\mathrm{J}=3.00 \mathrm{~Hz}), 7.49(\mathrm{~d}, 1 \mathrm{H}$, phenyl $\mathrm{H}, \mathrm{J}=3.00$ $\mathrm{Hz}), 7.43(\mathrm{~d}, 1 \mathrm{H}$, phenyl H, J = 3.30 Hz), $7.39(\mathrm{~d}, 1 \mathrm{H}$, phenyl H, J = $9.00 \mathrm{~Hz}), 7.16(\mathrm{~d}, 1 \mathrm{H}$, phenyl H, J = 2.40 Hz), $7.06(\mathrm{~d}, 1 \mathrm{H}$, phenyl $\mathrm{H}, \mathrm{J}=2.40 \mathrm{~Hz}), 6.93,6.90(\mathrm{dd}, 1 \mathrm{H}$, phenyl H, $\left.\mathrm{J}_{1}=8.70 \mathrm{~Hz}, \mathrm{~J}_{2}=2.70 \mathrm{~Hz}\right), 6.90,6.86\left(\mathrm{dd}, 1 \mathrm{H}\right.$, phenyl H, $\left.\mathrm{J}_{1}=8.70 \mathrm{~Hz}, \mathrm{~J}_{2}=2.70 \mathrm{~Hz}\right), 6.83$, $6.80\left(\mathrm{dd}, 1 \mathrm{H}\right.$, phenyl H, $\left.\mathrm{J}_{1}=8.70 \mathrm{~Hz}, \mathrm{~J}_{2}=2.70 \mathrm{~Hz}\right), 4.21\left(\mathrm{t}, 4 \mathrm{H}, \mathrm{PhOCH}_{2}\right), 3.89-3.55(\mathrm{~m}$, $22 \mathrm{H}, \mathrm{OCH}_{2}$ ), 3.39 (s. $6 \mathrm{H}, \mathrm{OCH}_{3}$ ), 1.89-0.88 (m, 9H, $\mathrm{CH}_{2}, \mathrm{CH}_{3}$ ), 0.22 (s, 9H, $\mathrm{Si}_{-} \mathrm{CH}_{3}$ ) ppm.

H-2TEG-1C ${ }_{5}{ }^{*}$-Trimer-I (8) One equivalent of the compound $7(69 \mathrm{mg})$ and 3 molar equivalents of $\mathrm{K}_{2} \mathrm{CO}_{3}$ with methanol $(11 \mathrm{~mL})$ and THF $(0.55 \mathrm{~mL})$ were stirred in a nitrogen-flushed flask for 0.5 to $4 \mathrm{~h}$. Reaction was monitored by TLC. Upon completion, the solution was diluted with ethyl acetate and water and washed twice with water. After drying the ethyl acetate layer over $\mathrm{MgSO}_{4}$ and evaporation of solvent, the residue was purified by flash column chromatography (100\% Ethyl acetate) to afford $0.06 \mathrm{~g}(95 \%)$ of 8.

${ }^{1} \mathrm{H}$ NMR $\left(\mathrm{CDCl}_{3}\right): \delta 7.54(\mathrm{~d}, 1 \mathrm{H}$, phenyl $\mathrm{H}, \mathrm{J}=6.30 \mathrm{~Hz}), 7.50(\mathrm{~d}, 1 \mathrm{H}$, phenyl $\mathrm{H}, \mathrm{J}=6.00$ $\mathrm{Hz}), 7.44(\mathrm{~d}, 1 \mathrm{H}$, phenyl H, J = 0.80 Hz), $7.43(\mathrm{~d}, 1 \mathrm{H}$, phenyl H, J = 5.10 Hz), $7.15(\mathrm{~d}, 1 \mathrm{H}$, phenyl H, J = 2.40 Hz), 7.09 (d, 1H, phenyl H, J = 2.40 Hz), 6.93, 6.90 (dd, 1H, phenyl H, $\left.\mathrm{J}_{1}=8.70 \mathrm{~Hz}, \mathrm{~J}_{2}=2.70 \mathrm{~Hz}\right), 6.90,6.87\left(\mathrm{dd}, 1 \mathrm{H}\right.$, phenyl H, $\left.\mathrm{J}_{1}=8.70 \mathrm{~Hz}, \mathrm{~J}_{2}=2.70 \mathrm{~Hz}\right), 6.85$, $6.81\left(\mathrm{dd}, 1 \mathrm{H}\right.$, phenyl H, $\left.\mathrm{J}_{1}=8.70 \mathrm{~Hz}, \mathrm{~J}_{2}=2.40 \mathrm{~Hz}\right), 4.21\left(\mathrm{t}, 4 \mathrm{H}, \mathrm{PhOCH}_{2}\right), 3.90-3.55(\mathrm{~m}$, $\left.22 \mathrm{H}, \mathrm{OCH}_{2}\right), 3.39\left(\mathrm{~s}, 6 \mathrm{H}, \mathrm{OCH}_{3}\right), 3.14\left(\mathrm{~s}, 1 \mathrm{H}\right.$, acetylene), 1.88-0.87 (m, 9H, $\left.\mathrm{CH}_{2}, \mathrm{CH}_{3}\right)$ 
ppm.

2TEG-1C 5 *-Macrocycle (M3) The general procedure for intramolecular Sonogashira cross-coupling was performed. $2.51 \mathrm{mg} \mathrm{Pd}\left(\mathrm{PPh}_{3}\right)_{2} \mathrm{Cl}_{2}(3.58 \mu \mathrm{mol}, 0.05 \mathrm{~mol}$ eq. $), 1.36 \mathrm{mg}$ $\mathrm{CuI}(7.15 \mu \mathrm{mol}, 0.1 \mathrm{~mol}$ eq.) and TEA were added to the air free flask under nitrogen, and then the solution was gently degassed for 30 minutes. $0.06 \mathrm{~g}$ of 8 (71.53 $\mu \mathrm{mol})$ was dissolved in TEA $(0.05 \mathrm{M})$ and added to the solution with a syringe pump (4.60 ml solution, flow rate: $0.08 \mathrm{~mL} / \mathrm{h}, 5 \mathrm{~mL}$ syringe). The reaction solution was heated at $65{ }^{\circ} \mathrm{C}$ during the $24 \mathrm{~h}$. Once done, the reaction solution was diluted with ether, filtered through a pad of Celite and concentrated. The oil was then purified using column chromatography $(30 \%$ Acetone : DCM) to afford the product (12.71 mg. $25 \%$ ) as a oily compound M3.

${ }^{1} \mathrm{H} \mathrm{NMR}\left(\mathrm{CDCl}_{3}\right): \delta 7.26(\mathrm{~d}, 3 \mathrm{H}$, phenyl $\mathrm{H}, \mathrm{J}=8.4 \mathrm{~Hz}), 6.85(\mathrm{t}, 3 \mathrm{H}$, phenyl H), 6.75-6.69 (m, 3H, phenyl H), 4.21 (t, 4H, $\left.\mathrm{PhOCH}_{2}\right), 3.90-3.55\left(\mathrm{~m}, 22 \mathrm{H}, \mathrm{OCH}_{2}\right), 3.39\left(\mathrm{~s}, 6 \mathrm{H}, \mathrm{OCH}_{3}\right)$, 1.88-0.87 (m, 9H, $\left.\mathrm{CH}_{2}, \mathrm{CH}_{3}\right)$ ppm. ${ }^{13} \mathrm{C} \mathrm{NMR}\left(\mathrm{CDCl}_{3}\right): \delta 159.64,159.09,159.06,133.52$, $128.81,128.72,118.81,118.71,118.25,117.03,115.67,93.47,93.32,93.15,91.54,91.43$, $91.28,72.14,71.10,70.89,70.82,69.78,67.76,59.30,34.84,26.29,16.72,11.54$ ppm. MS: $\mathrm{m} / \mathrm{z} 711.5\left(\mathrm{M}+\mathrm{H}^{+}\right)$. HPLC $\left(\mathrm{CH}_{3} \mathrm{CN}\right) 2.43 \mathrm{~min}(99 \%)$. 
Scheme 1. Synthesis symmetrically substituted ortho-phenylene ethynylene macrocycles ${ }^{\mathrm{a}}$

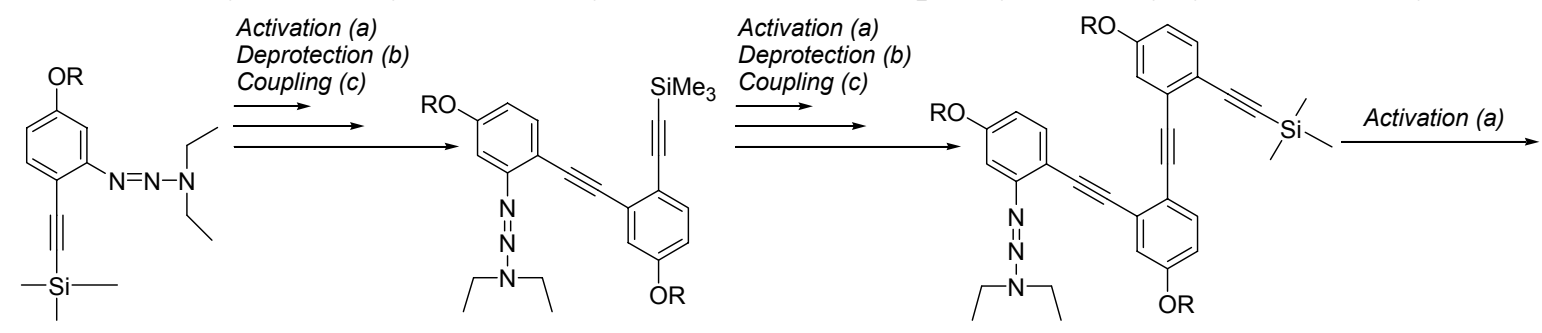

1a, 1b

$2 a, 2 b$

$3 a, 3 b$

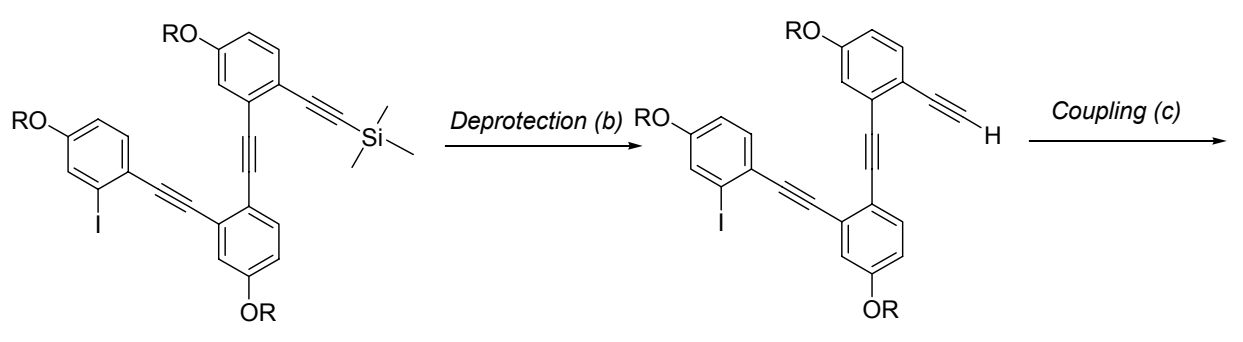

$4 a, 4 b$

$5 a, 5 b$

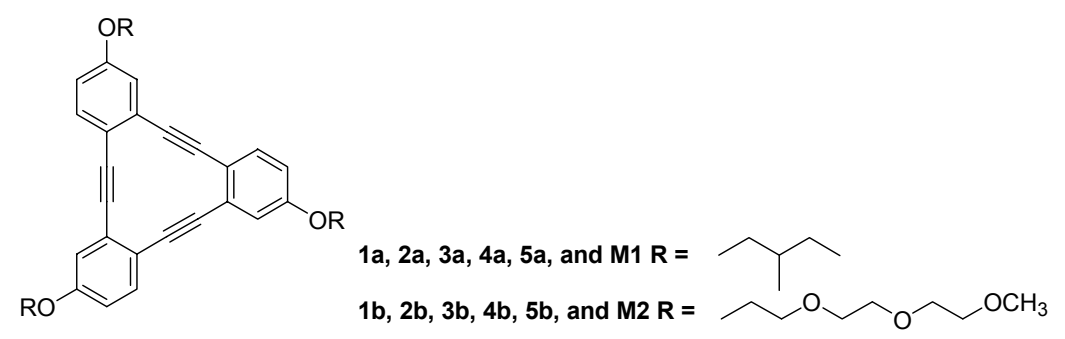

M1, M2

a Legend: (a) $\mathrm{CH}_{3} \mathrm{I}, 110^{\circ} \mathrm{C}, 12$ h. (b) $\mathrm{K}_{2} \mathrm{CO}_{3}, \mathrm{CH}_{3} \mathrm{OH}$, THF, rt, 6 h. (c) $\mathrm{Pd}\left(\mathrm{PPh}_{3}\right)_{2} \mathrm{Cl}_{2}$, CuI, TEA, $45^{\circ} \mathrm{C}, 18 \mathrm{~h}$. 
Scheme 2. Synthesis of asymmetrically substituted ortho-phenylene ethynylene macrocycle ${ }^{\mathrm{a}}$

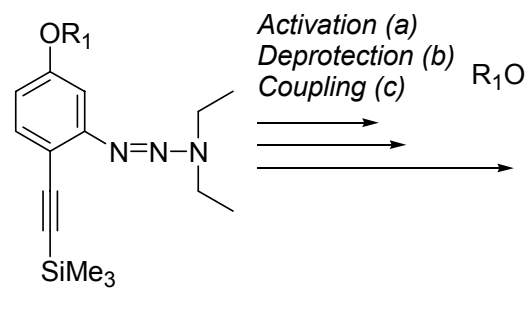

$1 b$<smiles>CC#Cc1ccc(OCC)cc1C#Cc1ccc(I)cc1/N=N/N(CC)CC</smiles>

$2 b$

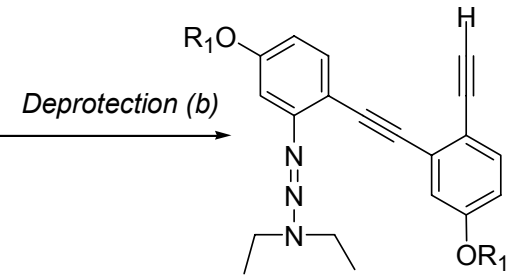

2b'<smiles>CC#Cc1ccc(OCC)cc1N=NN(CC)CC</smiles>

1a 1a'

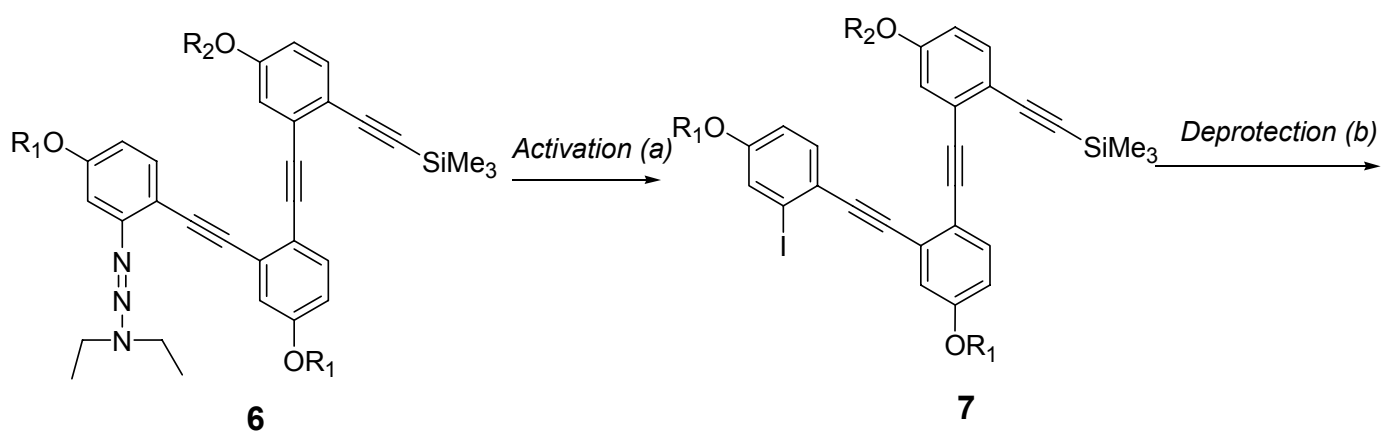

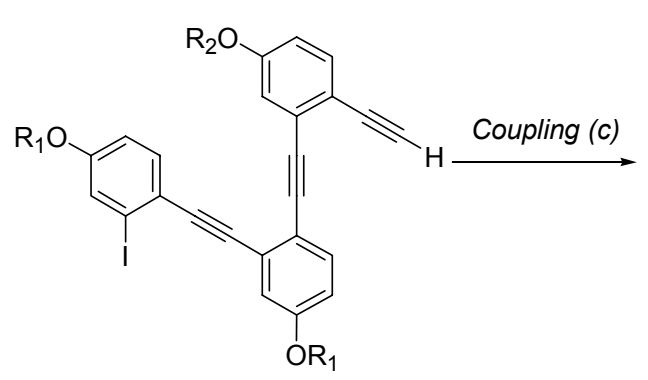<smiles>[R20]Oc1ccc(C#Cc2ccc(OCC)cc2C#Cc2ccc(O[R20])cc2C#Cc2ccccc2)c(O)c1</smiles>

8<smiles>[R7]CCOCCOCCOC</smiles>

a Legend: (a) $\mathrm{CH}_{3} \mathrm{I}, 110^{\circ} \mathrm{C}, 12$ h. (b) $\mathrm{K}_{2} \mathrm{CO}_{3}, \mathrm{CH}_{3} \mathrm{OH}, \mathrm{THF}, \mathrm{rt}, 6$ h. (c) $\mathrm{Pd}\left(\mathrm{PPh}_{3}\right)_{2} \mathrm{Cl}_{2}, \mathrm{CuI}$, TEA, $65^{\circ} \mathrm{C}, 24 \mathrm{~h}$. 


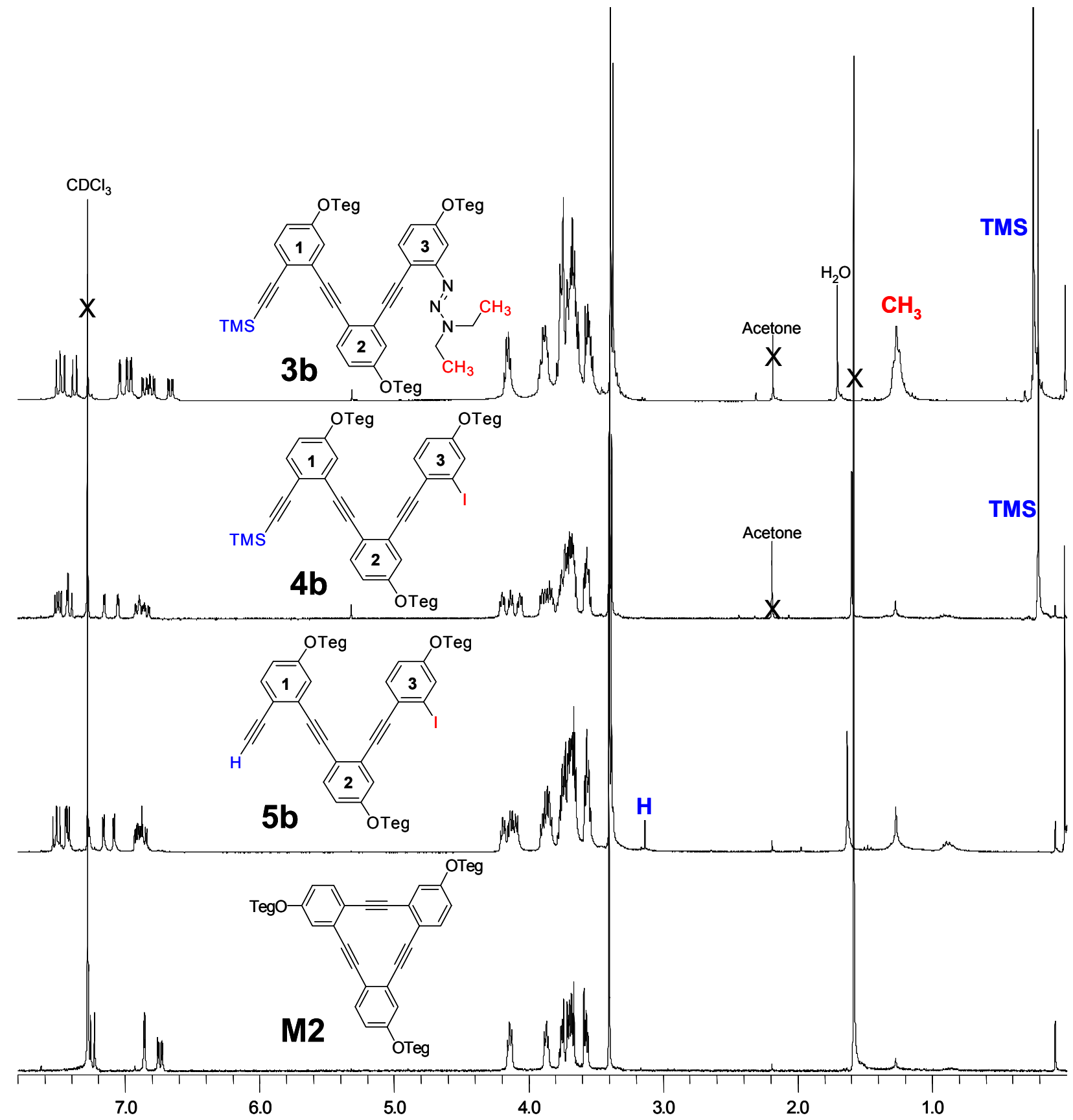

ppm Figure S1. Full NMR spectra of $3 b, 4 b, 5 b$, and M2 for comparison in deuterated chloroform, $300 \mathrm{MHz}$. 


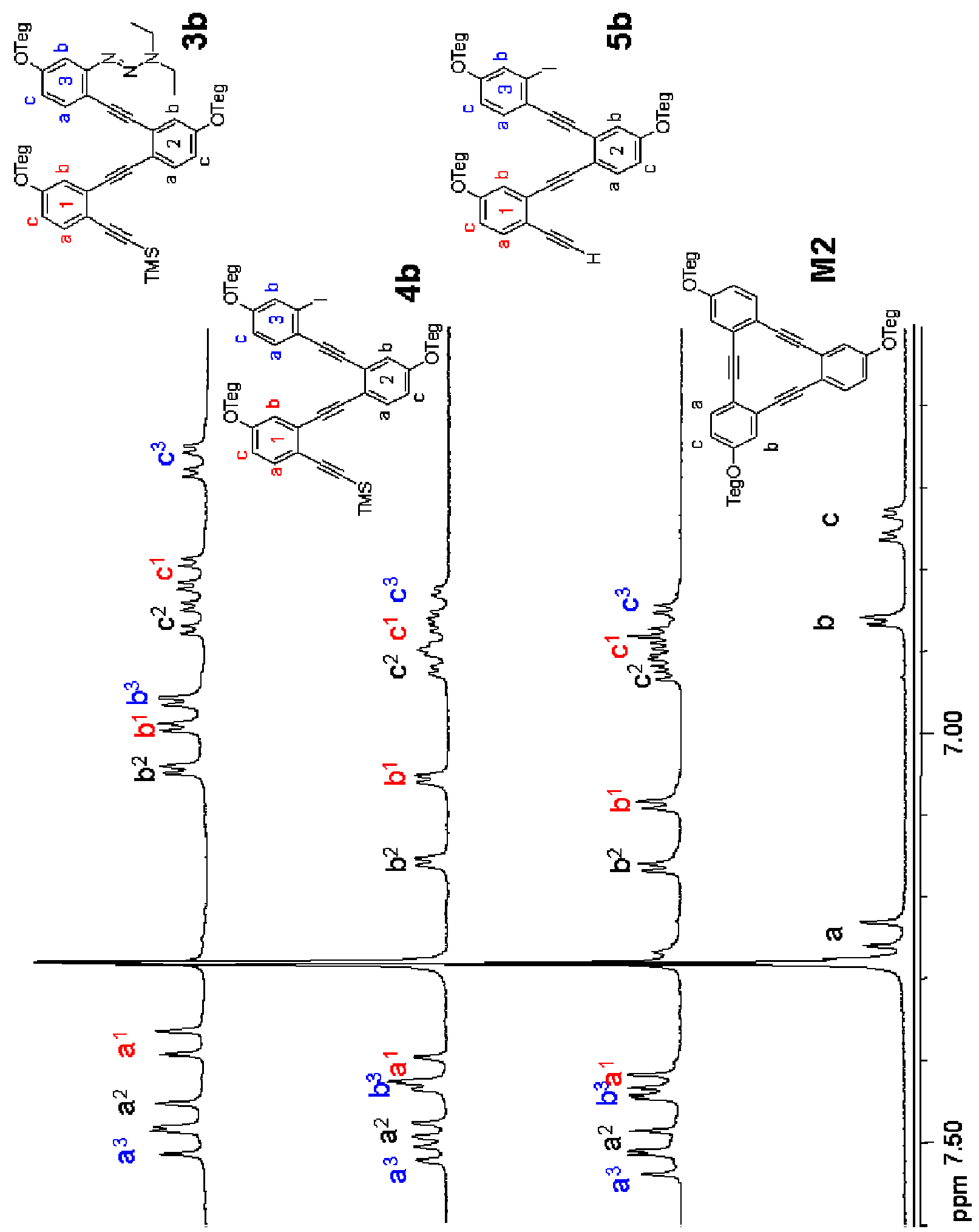

Figure S2. NMR of aryl region for compounds 3b, 4b, 5b, and $\mathbf{M 2}$ for comparison in deuterated chloroform, $300 \mathrm{MHz}$. 

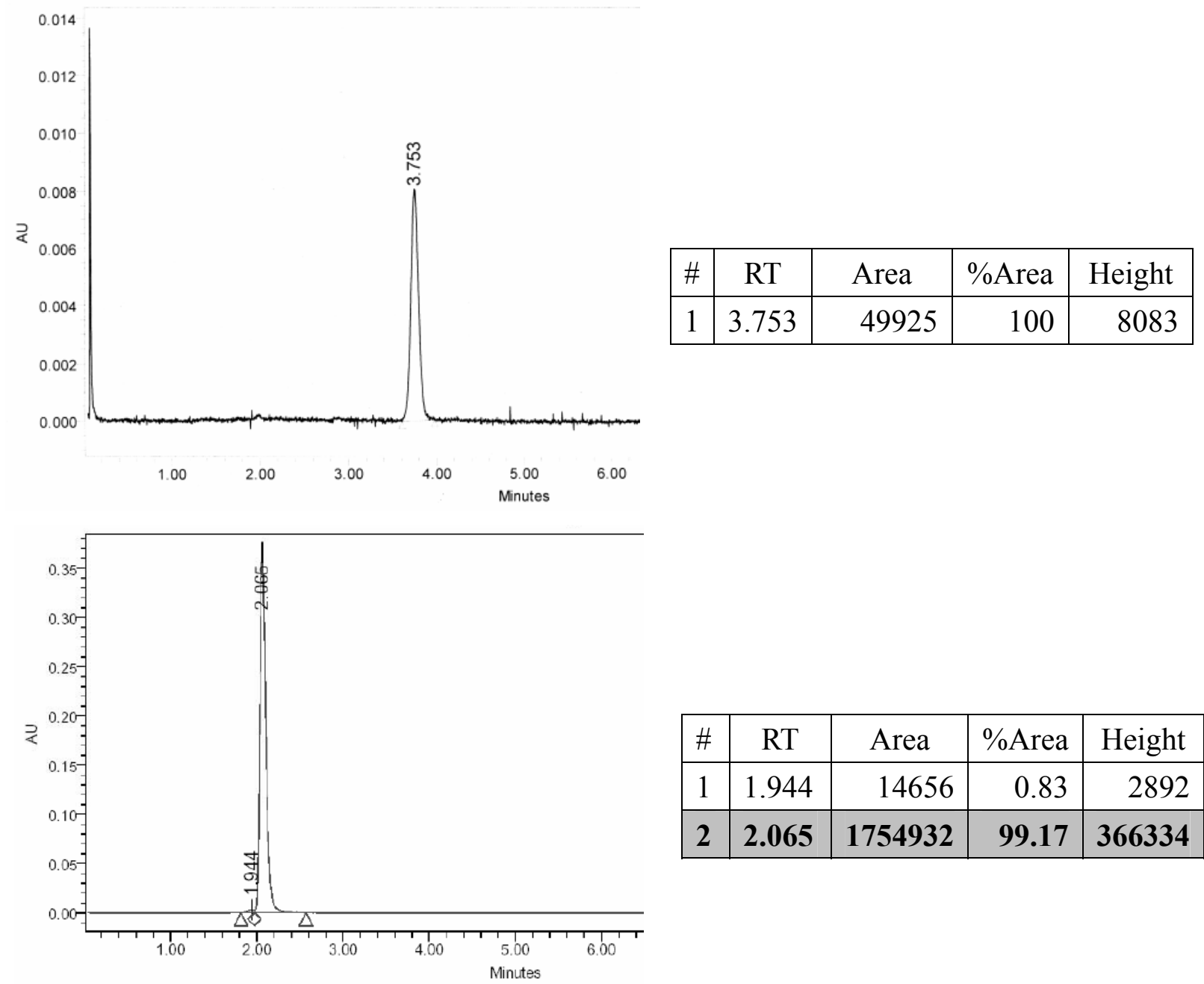

\begin{tabular}{|r|c|r|r|r|}
\hline$\#$ & RT & \multicolumn{1}{|c|}{ Area } & \%Area & Height \\
\hline 1 & 1.944 & 14656 & 0.83 & 2892 \\
\hline $\mathbf{2}$ & $\mathbf{2 . 0 6 5}$ & $\mathbf{1 7 5 4 9 3 2}$ & $\mathbf{9 9 . 1 7}$ & $\mathbf{3 6 6 3 3 4}$ \\
\hline
\end{tabular}

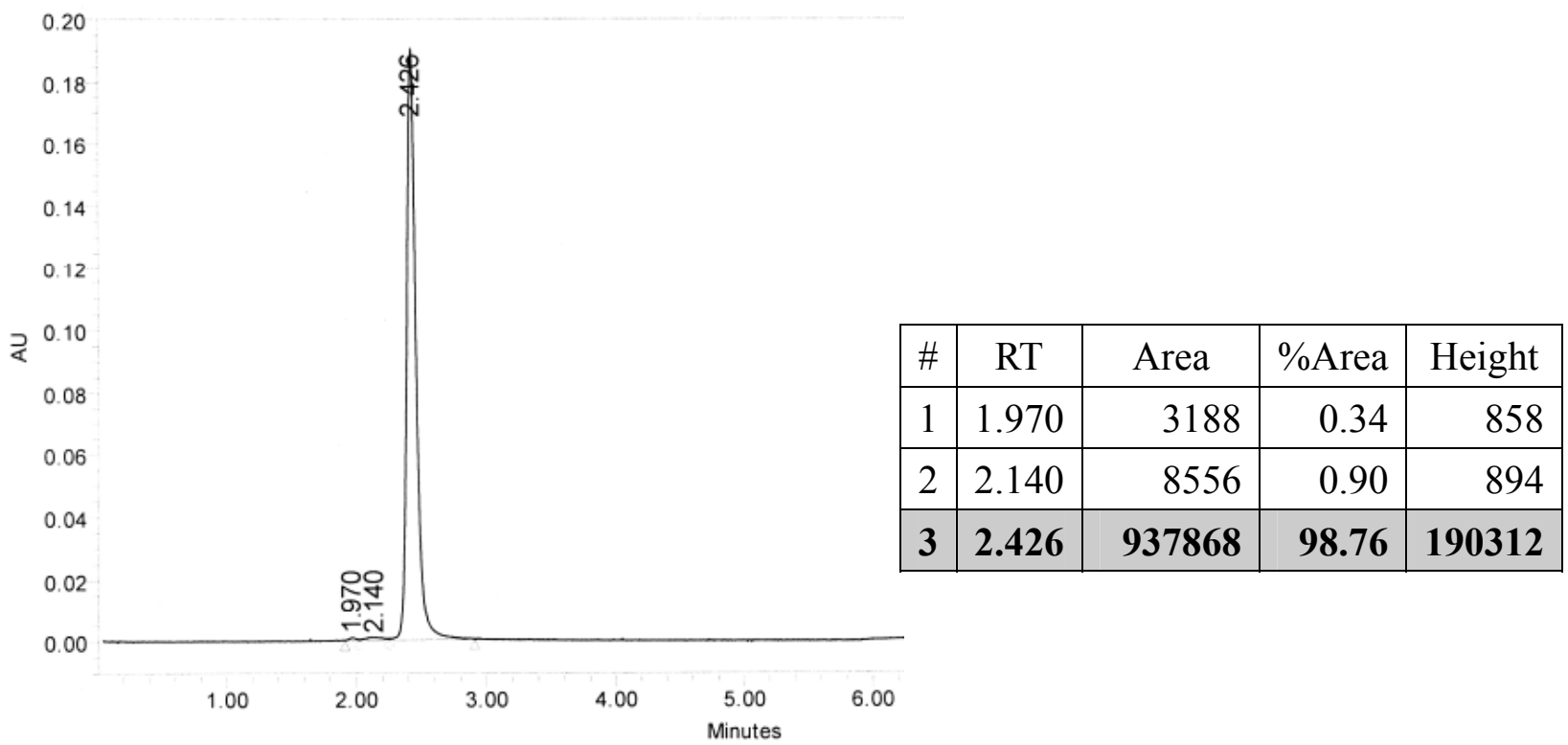

Figure S3. HPLC traces of M1 (a) M2(b) and M3 (c) in Acetonitrile monitored at 290nm. Purity by integration is shown for each trace to the right. All Macrocycles are $>98 \%$ pure by HPLC. 

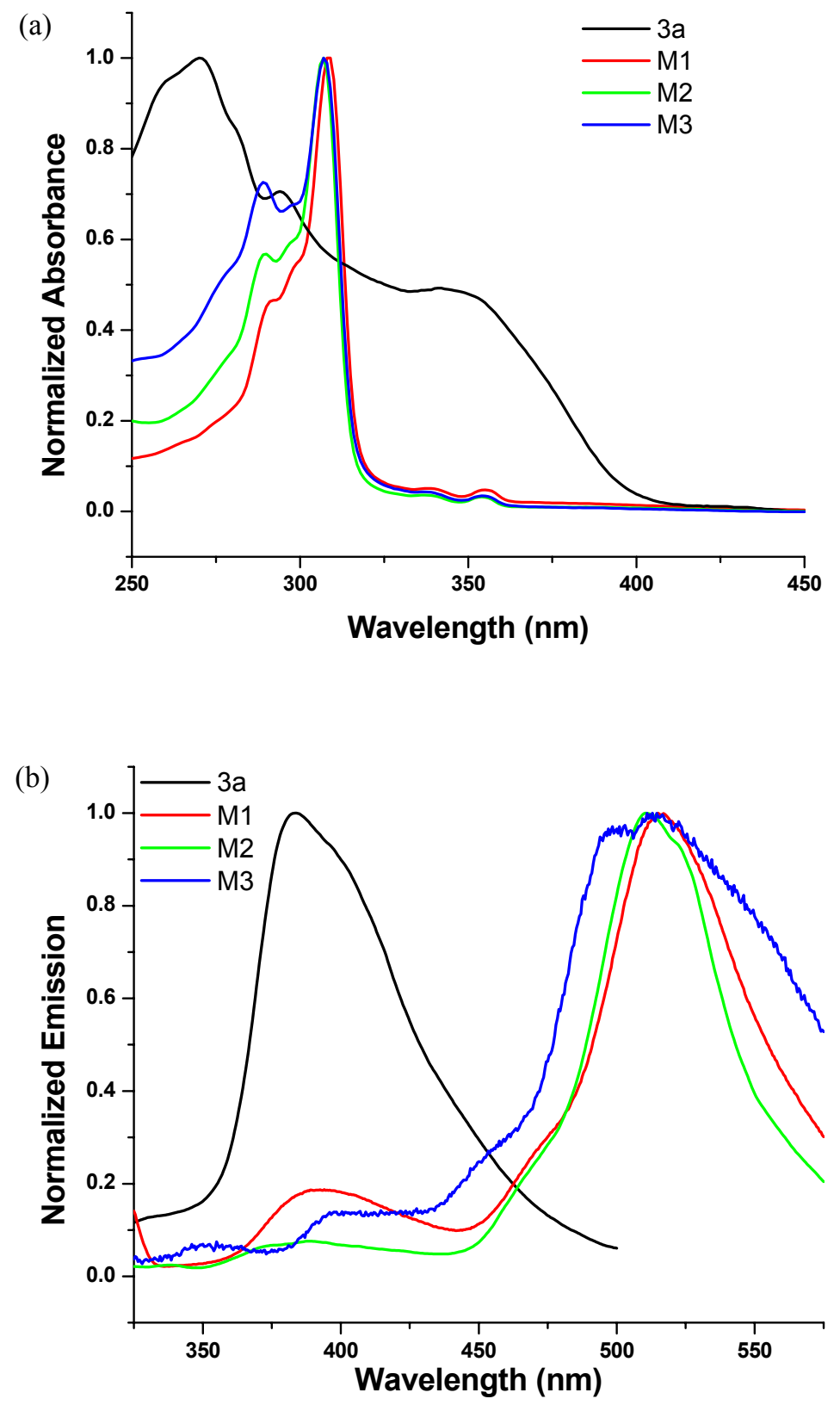

Figure S4. Normalized UV (a) and fluorescence (b) spectra of trimer 3a, macrocycles (M1, M2, and M3) in chloroform $\left(\lambda_{\mathrm{ex}}=308 \mathrm{~nm}\right)$. 

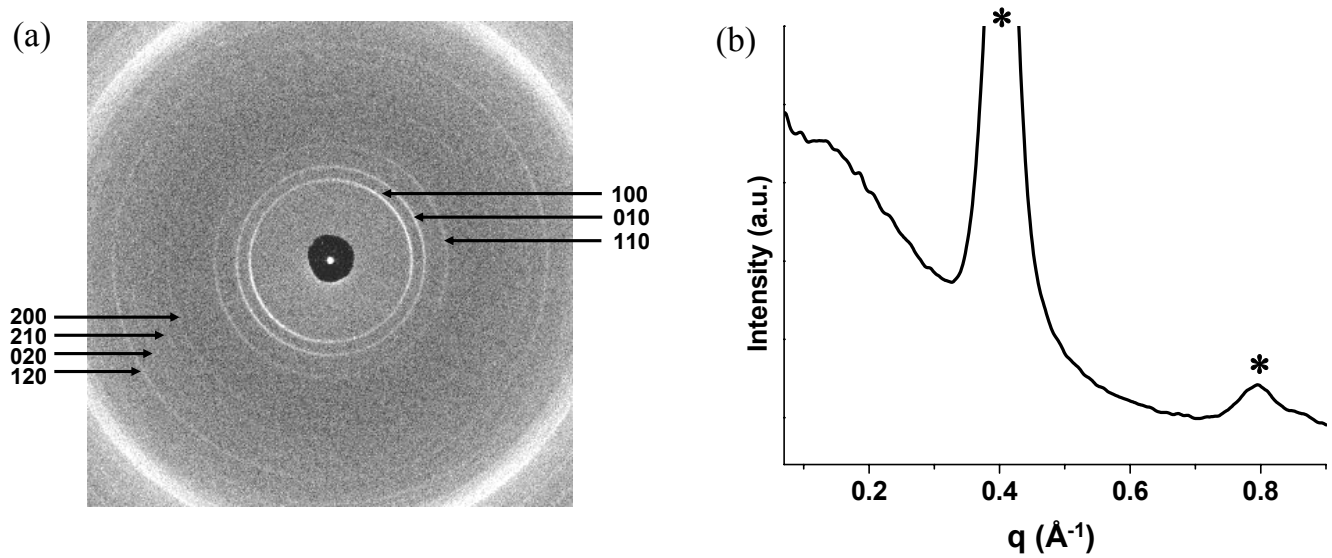

Figure S5. (a) 3D X-ray diffraction of columnar rectangular phase for M1 (b) X-ray diffractogram of discoic nematic phase for M3 obtained at room temperature. The asterisks (*) denote diffraction peaks of imide film used as substrate. 

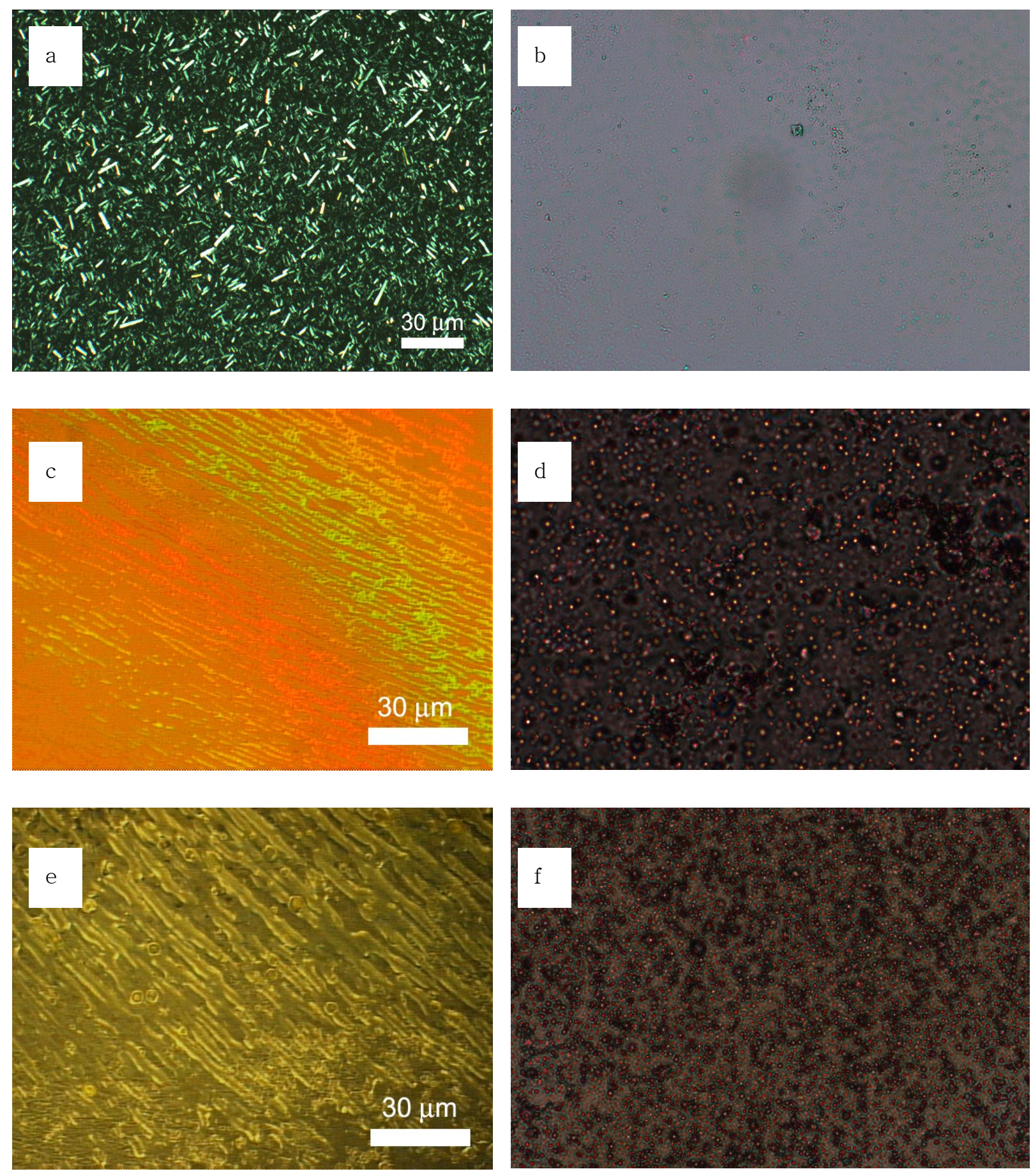

Figure S6. Optical microscopy images for M1 (a, b), M2 (c, d), and M3 (e, f). The images in the left column are with cross-polars and the images in the right column are without cross-polars. These comparisons show that the textures observed with crosspolarizers are not from small insoluble impurities which might be expected due to the "nonclassical' textures observed in the left column. 
Table S1. Small angle X-ray diffraction data for the macrocycles.

\begin{tabular}{|c|c|c|c|c|}
\hline Compound & Phase & $\begin{array}{l}d_{\mathrm{obs}} \\
{[\AA]}\end{array}$ & $h k l$ & $\begin{array}{l}\text { Lattice } \\
\text { Constants }[\AA]\end{array}$ \\
\hline \multirow[t]{7}{*}{ M1 } & $\mathrm{Col}_{\mathrm{r}}$ & 17.9 & 100 & $a=17.9$ \\
\hline & & 15.3 & 010 & $b=15.3$ \\
\hline & & 12.3 & 110 & \\
\hline & & 8.9 & 200 & \\
\hline & & 8.2 & 210 & \\
\hline & & 7.4 & 020 & \\
\hline & & 6.8 & 120 & \\
\hline \multirow[t]{4}{*}{ M2 } & $\mathrm{Col}_{\mathrm{h}}$ & 20.6 & 100 & $a=23.8$ \\
\hline & & 12.1 & 110 & \\
\hline & & 10.4 & 200 & \\
\hline & & 7.8 & 210 & \\
\hline M3 & $\mathrm{N}_{\mathrm{D}}$ & 44.0 & & \\
\hline
\end{tabular}

$\mathrm{Col}_{\mathrm{r}}$ : rectangular columnar phase; $\mathrm{Col}_{\mathrm{h}}$ : hexagonal columnar phase; $\mathrm{N}_{\mathrm{D}}$ : discotic nematic.

References:

4. (a) Jones, T. V.; Blatchly, R. A.; Tew, G. N. Org. Lett. 2003, 5, 3297. (c) Jones, T. V.;

Slutsky, M. M.; Laos, R.; de Greef, T. F. A.; Tew, G. N. J. Am. Chem. Soc. 2005, 127, 17235. 